覧床腎石灰化症を伴つた正レニン性正血圧性

原発性アルドステロン症の 1 例

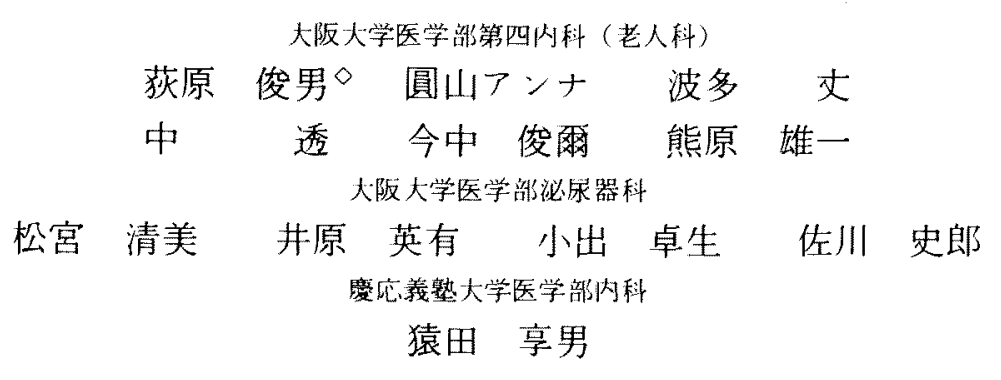

\title{
A CASE OF NORMORENINEMIC NORMOTENSIVE PRIMARY ALDOSTERONISM ASSOCIATED WITH NEPHROCALCINOSIS
}

Toshio Ogihara, MD, Anna Maruyama, MD, Takeshi Hata, MD,

Toru NaKa, MD, Shunji Imanaka, MD and Yuichi Kumahara, MD

Department of Medicine and Geriatrics, Osaka University Medical School, Osaka

Kiyomi Matsumiya, MD, Hideari Ihara, MD, Takuo KoIde, MD

and Shiro Sagawa, MD

Department of Urology, Osaka University Medical School, Osaka

Takao Saruta, MD

Department of Medicine, Keio University, Tokyo

\begin{abstract}
概要 正血圧性原発性フルドステロン症はSnowら以来，4例の報告がみられる.我々も著明な 低 $\mathrm{K}$ 血症を呈する女性で，腎石灰化症を伴つた正レニン性正血厈性と考克られる原発性アルド ステロン症の手術例を経験し，その病態について内分泌学的検討を加えた，症例は，36才女性. 8 年前より四肢脱力発作を年に 1 ～ 2 回経験, 高血圧も指摘されていたが放置. 外来時血王174/ 104. 入院翌日より血圧は $120 / 80$ 前後に正常化. 家族歴に両親とも高血王. 理学的所見では筋力 低下著明。トルーソー,クボステク徵候陽性.一般検査で, 検尿異常なく, 低K血性代謝性了 ルカローシスを認めた。腎機能では尿濃縮能障害のほか異常なく, 腎孟撮影にて腎に小石灰化 を多数認めた．PRAは1.0 1.5ng/ml/hで，減塩食，立位，フロセマイド投与で増加反応を認 めた，血倸アルドステロンは70８0ng/dlで，各種刺激によつて反応は認めず。入院中術前の血 压は減塩食下で低下，増塩食で上昇し，Naバランスに体存した。昇王ホルモンに対する血王反 応正常. 循環血浆量は正常. 左副腎腺腫摘除後, 血王はやや降下. 血清Kは正常化, PRAはや や上算。腎生㛟では尿細管に石灰化, 旁系球体装置は正常であつた。退院後外来時の血圧は160/ 100 と上昇し, 本症の高血王は本態性高血王の合併と考克られた。正レニン, 正血圧の原因につ いては降正ホルモン， Na表失機作の有無など検索するも明解な結論は得られず，督石灰化症の 原因も不明であった。
\end{abstract}

[昭和56年 3 月 2 日受稿〕 


\section{緒 言}

正血圧性原発性アルト゚ステロン症はSnow ら ${ }^{1)}$, Zipserら に2より報告されて以来，本邦でも Shiroto $5^{3)}$, Kono $5^{4)}$ にり発見されて扣り，そ の病態, 特に血圧が正常範囲内に留委る原因につ いて注目され，種々検索がなされているが，末だ 明解な説明はなされていない，最近, 我々は著し い低カリウム血症を呈する36才の女性で，督石灰 化症伴つた正レニン性正血王性原発性アルドス テロン症と考えられる1手術例を経験し，内分泌 学的検討を加えたので報告する。

\section{症 例}

症例：MK, 36才, 女性。

主訴: 四肢脱力発作.

家族歴：而親共高血王.

既往歴：特記すべきことなし．

現病歴： 8 年前より四肢脱力発作，テタニー 様発作を年に 1 ～ 2 回経験. 発作は $2 \sim 3$ 日で自 然に軽快した。なた当時より近医にて高血王を指 摘されていたが放置していた，外来受診時の血王 は174/140mmHgと高血王を示したが，入院翌日 より血王は $120 / 80 \mathrm{mmHg}$ 前後に正常化した。释 は整，便通 $1 \times 1$ 日，正常。薬物の常用なし。

入院時現症：身長 $161 \mathrm{~cm}$, 体重 $57 \mathrm{~kg}$, 血王 $120 / 80 \mathrm{mmHg}$ (左右差，上下肢差なし）。脈拍 60 / 分, 整。貧血, 黄疸なし。甲状腺触知せず。胸部, 腹部異常なし、全身の筋力低下著明.トルーソー, クボステク徵候陽性. 病的反射は認めず, 浮腫認 めず。性器発育に異常なく，二次性徵は正常.

\section{一般検查成績：検尿は蛋白 (一), 糖 (一),}

沈渣異常なし, $\mathrm{pH} 6.0$, ウロビリノーゲン正常. 血 清 $\mathrm{Na} 143, \mathrm{~K} 2.3, \mathrm{Cl} 99 \mathrm{mEq} / l$, Ca $9.4 \mathrm{mg} / \mathrm{dl}$, P 3.7, BUN 9, クレアチニン0.9, コレステロー 儿 183 ，尿酸 $5.2 \mathrm{mg} / \mathrm{dl}$ と著明な低 $\mathrm{K}$ 血症がみられ た。尿中Nal72，K $34 ， \mathrm{Cl} 164$, Ca $10.4 \mathrm{mEq} /$ 日， P $338 \mathrm{mg} /$ 日と尿中K排泄量は増加, 。動脈血ガス 分析ではpH 7.482, $\mathrm{Po}_{2} 82.4, \mathrm{Pco}_{2} 43.6 \mathrm{mmHg}$, $\left[\mathrm{HCO}_{3}^{-}\right] 32 \mathrm{mEq} / l, \mathrm{BE}+7.8$ と代謝性アルカロー ジスを示した。腎機能はPSP 26\%（15分）, GFR $70, \mathrm{RPF} 368 \mathrm{ml} / \mathrm{min}$, 内因性クレアチニンクリア
ランス $75 \mathrm{ml} / \mathrm{min}$, Fishberg濃縮テスト 1.008 と 濃縮能に異常を認めた。千才硫酸ソーダ負荷時に

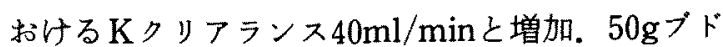
ウ糖負荷試験では血糖値 0 分95，30分 $179 ， 60$ 分 197,120 分 $168 \mathrm{mg} / \mathrm{dl}$ と耐糖能の低下を認めた。 そ の他，末梢血液像，肝機能検査では異常を認めな かつた。眼底 $\mathrm{H}_{1}$ So，心電図 $\mathrm{T}$ 波平低化，U波著明。 胸部 $\mathrm{X}$ 線像異常なく, 腹部単純 $\mathrm{X}$ 線像, 腎盂撮影 で両側腎に散在性小石兏化像を認めた。

内分泌機能検査：甲状腺機能 $\mathrm{T}_{4} 9.1 \mu \mathrm{g} / \mathrm{dl}$, $\mathrm{T}_{3} 147 \mathrm{ng} / \mathrm{dl}, \mathrm{T}_{3} \mathrm{U} 25 \%$, カルシトニン $<25 \mathrm{pg} / \mathrm{ml}$, 副甲状腺機能PTH $100 \mathrm{pg} / \mathrm{ml}$, TRP (リン尿細管 再吸収率) $91 \%$ 。下垂体機能 $\mathrm{GH} 3 \mathrm{ng} / \mathrm{ml}, \mathrm{ACTH}$ $38 \mathrm{pg} / \mathrm{ml}(8: 00 \mathrm{a} \mathrm{m}$.), TSH $3 \mu \mathrm{U} / \mathrm{ml}$, ADH 1.0 $\mathrm{pg} / \mathrm{ml}$ ，副腎皮質機能尿中 $17-\mathrm{OHCS} 4.9 \mathrm{mg} /$ 日， 17-KS $3.3 \mathrm{mg} /$ 日，血浆コルチゾール $11.9 \mu \mathrm{g} / \mathrm{dl}(8:$ $00 \mathrm{a} \mathrm{m})$ ，カテュラミン系で尿中VMA $9 \mathrm{mg} /$ 日， 尿中ノルアドレナリン $80 \mu \mathrm{g} /$ 日，尿中アドレナリ ソ $9 \mu \mathrm{g} /$ 日といずれる正常範囲であつた.

$$
\text { レニンーアンジオテンシンーアルドステロン }
$$
系： レニンーアンジオテンシンーフルドステロ ソ系に関する検查結果を表 1 に一覧表とした。血 浆レニン活性（PRA）は1 1.5ng/ml/h（臥位）, 血浆アルドステロン濃度（PAC）は70～80ng/dl (臥位)であり，PRAは正常範囲内にあり，PACは 著增していた，PRAは立体，減塩，フロセマイド 負荷, カプトプリル5投与で上昇し，生食水負荷， 増塩食で抑制された。一方PACはこれら刺激に対 して一定の変動を示さず。アンジオテンシンIIア ナログ6)和よびACTHに対しては上昇反応を示し た（表 1).

腫瘍の局所診断： デキサメサゾン抑制後 の ${ }^{131} \mathrm{I}$ ーアドステロールによる副腎シンチグラムで は左副腎部に有意の取り込みを認めた。腹部CTス キャンでも左副腎部に腫疼陰影を認めた。さらに 副腎静脈造影で左副腎腫湯を確認した。この際採 取した副腎静脈血中アルドステロン濃度は左 1,298ng/dl, 右 46ng/dlであり,これらの結果より 左側副腎のアルドステロン産生腫瘍が確認され た。 
CLIMICAL COURSE

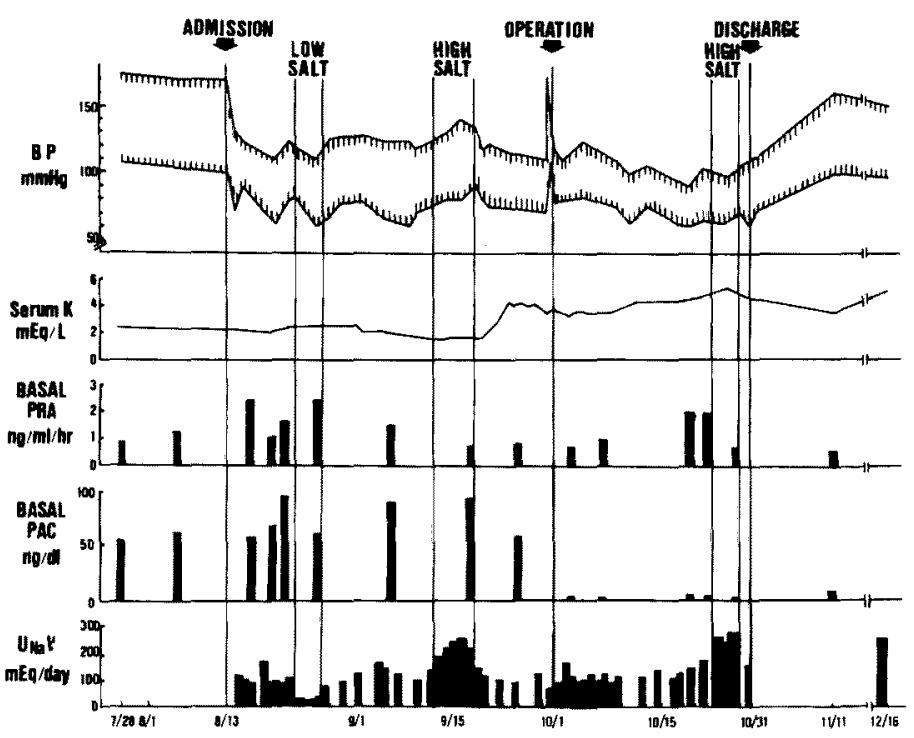

困 1。血珐ならびに検查值の経過.

表 1。各種条件下に括けるPRAおよびPAC

\begin{tabular}{|c|c|c|c|c|}
\hline & $\underset{(m E q / 24 h r)}{U N_{s} V}$ & & $\begin{array}{c}\text { PRA } \\
(\mathrm{ng} / \mathrm{m} / \mathrm{hr})\end{array}$ & $\begin{array}{c}\text { PAC } \\
(\mathrm{DB} / \mathrm{m})\end{array}$ \\
\hline \multirow{2}{*}{ 常 } & \multirow{2}{*}{$120 \sim 170$} & 臣妍 & 1.5 & 800 \\
\hline & & 童位 & 2.0 & 646 \\
\hline \multirow{2}{*}{ 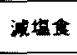 } & \multirow{2}{*}{$20-25$} & 卧焦 & 2.5 & 800 \\
\hline & & 童位 & 3.3 & 480 \\
\hline 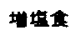 & $250 \sim 300$ & 即位 & 0.7 & 920 \\
\hline
\end{tabular}

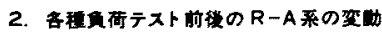

\begin{tabular}{|c|c|c|c|}
\hline 菏 & & 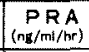 & $\begin{array}{c}\text { PAC } \\
(\mathrm{gB} / \mathrm{m})\end{array}$ \\
\hline \multirow{2}{*}{ 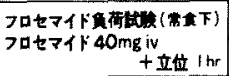 } & 䛔 & 1.1 & 744 \\
\hline & 传 & 1.7 & 964 \\
\hline \multirow{2}{*}{ 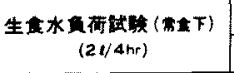 } & 前 & 1.5 & 790 \\
\hline & 挠 & 1.1 & 680 \\
\hline \multirow{2}{*}{ 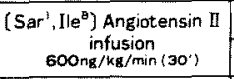 } & 䛔 & 1.1 & 667 \\
\hline & 後 & 1.3 & 1018 \\
\hline \multirow{2}{*}{$\begin{array}{c}\text { カフトプリルー回投与 } \\
100 \mathrm{mg} \text {. } 0.0 .\end{array}$} & 前 & 1.2 & 380 \\
\hline & 挠 & 1.9 & 376 \\
\hline \multirow{2}{*}{$\begin{array}{l}\text { Angiotensin II infusion } \\
20 \mathrm{ng} / \mathrm{kg} / \min \left(30^{\circ}\right)\end{array}$} & 前 & 1.2 & 730 \\
\hline & 挠 & 1.1 & 799 \\
\hline \multirow{2}{*}{ 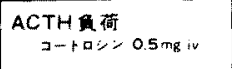 } & 前 & 1.2 & 744 \\
\hline & 挠 & 0.6 & 985 \\
\hline
\end{tabular}

組織学的所見：諸検查施行後, 左副腎摘除術 ならびに腎生検を行なつた。副腎には直経 $2.3 \mathrm{~cm}$ の腫瘍を認め組織学的には良性腺腫であつた。腎 組織は尿細管に散在性石灰化を認め, nephrocal- cinosis と診断された。系球体，間質には異常を認 めなかつた。Bowie染色による傍系球体装置は正 常であり、レニン顆粒も正常に認められた.Juxta glomerular index ${ }^{7)}$ は9.0 (正常 3－15)であつた.

入院後経過(図 1)：入院翌日より血王は降下 し，以啳，入院中は正常範囲内に留まつた。手術 後，血圧はさらに低下傾向にあつたが，退院10日 後，外来時血圧は再び $160 / 100 \mathrm{mmHg}$ と上昇して いた，血清 Kは術後正常化，PAC 術後正常範囲 内に低下した，PRAは術後やや上昇，外来時は正 常範囲内であつた(図 1). その他, 術後動脈血ガ ス正常化，筋力も回復，麻瘏発作はみられなくな つた。

\section{血圧調節機構に関する検索結果：}

（1）食塩バランスと血圧との関係(因 2). 術前, $\mathrm{Na}$ 攝取量を $20 \mathrm{mEq} /$ 日， $160 \mathrm{mEq} /$ 日，280mEq/日 と変化せしめた際の血圧は，図 2 に示すごとく増 塩により上昇する傾向を認めた。術後，常食，増 塩時の血圧は，術前に比し，低値を示した。外来 時の血圧は術前，術後共高血王を示した。なお術 後外来時の尿中Na排泄量は入院中の増塩時之同 程度であつた。 
（2）特殊検査結果。（a）循環血浆量； RISA を用いて測定した循環血装量は常食時 $50.2 \mathrm{ml} / \mathrm{kg}$ （正常 $45 \pm 5$ ）増塩食時 $49.4 \mathrm{ml} / \mathrm{kg}$, 術後 $42.9 \mathrm{ml}$ / kgであり，いずれも正常範囲内であつた（b）ス テロイドホルモン；血浆 DOC $0.33 \mathrm{ng} / \mathrm{ml}$ (0.01 0.3), コルチコステロン $6.2 \mathrm{ng} / \mathrm{ml}$ $(0.5 \sim 10)$, プロゲステロン $0.49 \mathrm{ng} / \mathrm{ml}$

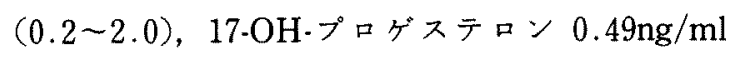
(0.2 2.0), とDOCの軽度上昇を認めた. 腺腫中 のホルモン測定では, DOC $3.9 \mu \mathrm{g} /$ tissue $(0.2 \sim 0.7)$, コルチコステロソ $11.4 \mu \mathrm{g} /$ tissue $(2.2 \sim 6.7)$, アルドステロン $1.6 \mu \mathrm{g} /$ tissue (0.2〜0.7)といずれも上昇していた.（c）尿細管 $\mathrm{Cl}$ 再吸收試験； $\mathrm{Gills}^{8)}$ の方法に従つて行なつた 尿細管 $\mathrm{Cl}$ 再吸收試験は $\mathrm{CH}_{2} \mathrm{O} / \mathrm{CH}_{2} \mathrm{O}+\mathrm{Cc} 1=$ 0.89 (正常 $0.86 \pm 0.04$ )であった.（d）降王系木 ルモン; 尿中カリクレイン排泄量は 1,464 $\mathrm{nmol} / \mathrm{min} /$ 日 (MCA法, 正常 200 600). ラジオ イムノアッセイ法によるプロスタグランディン (PG) 測定では，尿中PGE 700ng/日 $(300 \sim 1500)$, 血中PGE $100 \mathrm{pg} / \mathrm{ml}(<150), \mathrm{PGF}_{2} \alpha 30 \mathrm{pg} / \mathrm{ml}(<$ 150)といずれも正常範囲内にあつた。（e）血王反 応検査；外因性アンジオテンシンII 拉よびノル エピネフリン投与による昇圧反応はいずれも正常 範囲内であつた(図 3 ). アンジオテンシンIIアナ ログ5) $\left(\left[\mathrm{Sar}^{1}, \mathrm{Ile}^{8}\right]\right.$ ANGII $) 600 \mathrm{ng} / \mathrm{kg} / \mathrm{min} 30$

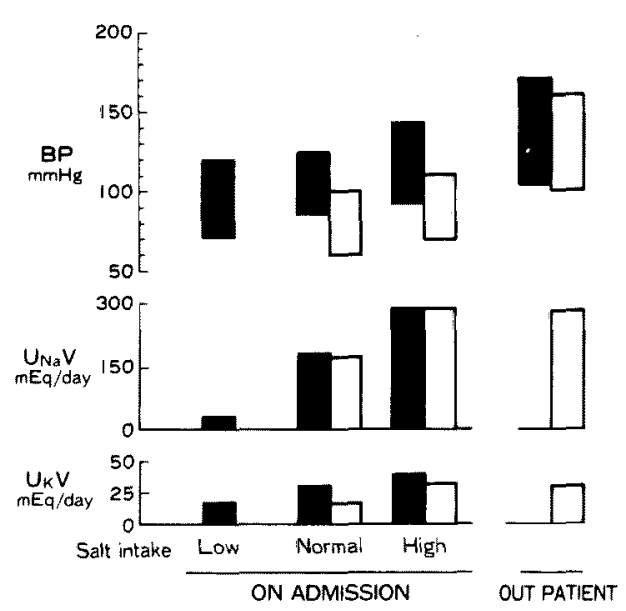

図 2、食塩バランスと血圧との関係、日：術前，口：術後

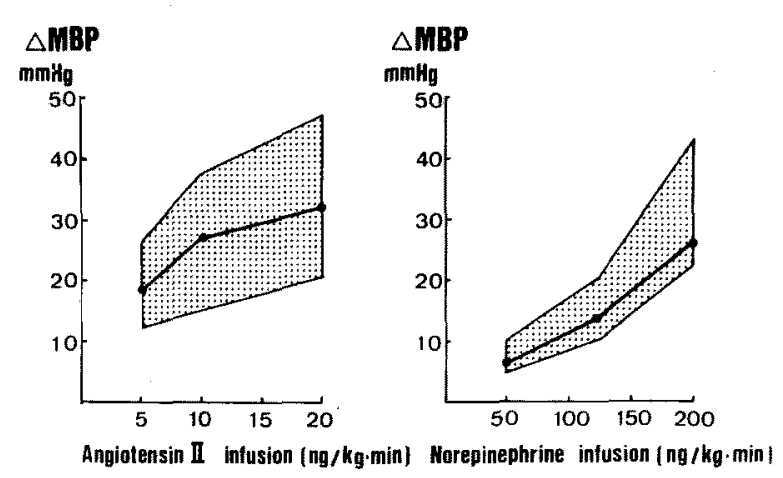

図3。界圧ホルモンに対する血管反応性.

分投与により平均血圧 $+24 \mathrm{mmHg}$ (減塩処置後) と昇王反応を示した，変換酵素抑制薬カプトプリ

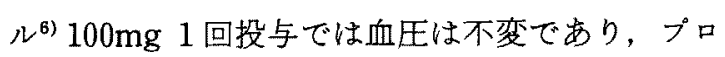
スタグランディン合成阻害薬であるibuprofen $600 \mathrm{mg} 3$ 日間投与にても血圧は不変であつた。

\section{考案}

本症は生理的食塩水負荷により抑制されない高 アルドステロン血症，アルドステロン含量の高い 副腎腺腫の証明により，腺腫による原発性アルド ステロン症と診断される。低 $\mathrm{K}$ 血症, 尿中 $\mathrm{K}$ 排泄 増加, 代謝性アルカロージスは高アルドステロン 血症によるものである。血圧については，入院翌 日より正常血圧になつたこと，術後正常血珐であ つたものが, 退院後, 外来受診時には再び高血圧 になつたこと、家族煌が濃厚であることなどより， 本症に外来時みられた高血王は本態性高血圧の合 併によるすのと考えられる。ささらに本例で興味深 い点は原因不明のnephrocalcinosis 伴つた点, 扣よびPRAが正常範囲内にあつた点である。

Nephrocalcinosisは,一般的に腎結核, 副甲状腺 機能立進症, 腎尿細管性アチドーシス, medullary sponge kidneyなどが考兄られるが，いずれも臨 床検查执よび組織学的検査により否定された。一 般に原発性アルドステロン症ではカルシウム代謝 は正常であり ${ }^{9)}$, 本症においても明らかなカルン ウム代謝調節ホルモンの異常は認められず,nephrocalcinosisの原因は不明である。

PRAが正常範囲内にあつた点については，既に 報告されている4 例では，PRAはいずれも㧕制さ 
表 2、正血正性原発性フルト゚ステロソ症の報告例.

\begin{tabular}{|c|c|c|c|c|c|c|c|c|c|}
\hline Author & $A G E$ & SEX & $\mathrm{BP}$ & $\begin{array}{l}\text { SERUM } \\
\mathrm{K} \\
\mathrm{mEq} / 1\end{array}$ & $\begin{array}{l}\text { PRA } \\
\text { ng/ml/hr }\end{array}$ & $\begin{array}{l}\text { PLASMA } \\
\text { ALDO- } \\
\text { STERONE } \\
\text { Dg/MI }\end{array}$ & HISTOLOGY & SUGGESTED MECHANISM & REFER \\
\hline Snow et of & 40 & M & $133 / 85$ & 2.4 & $\begin{array}{l}\text { less that } \\
\text { sensitiv. }\end{array}$ & 425 & odenomo & $\begin{array}{l}\text { Plack of concomitont over- } \\
\text { production of DOC, 18-OH- } \\
\text { DOC or corticosterone }\end{array}$ & $\begin{array}{l}\text { Br. } \\
\text { Hed. }\end{array}$ \\
\hline $\begin{array}{r}\text { Zlpser et } \\
\text { al }\end{array}$ & 45 & $\mathrm{~F}$ & $110 / 76$ & 3.1 & $\begin{array}{c}1.1 \\
(3-6)\end{array}$ & 149 & $\begin{array}{l}\text { bllat. } \\
\text { hyper- } \\
\text { plasio }\end{array}$ & $\begin{array}{l}\text { ?short duration for trophi } \\
\text { stimulus }\end{array}$ & {$\left[\begin{array}{c}\text { Alln } \\
\text { Int } \\
\text { Med. } \\
1973\end{array}\right.$} \\
\hline $\begin{array}{l}\text { Shlroto } \\
\text { et al }\end{array}$ & 25 & $F$ & $125 / 35$ & 2.4 & 0.2 & 524 & odenoma & $\begin{array}{l}\text { hyporesponse to onglotensir } \\
\text { II or noreplnephrine, } \\
\text { orlginally hypotensive }\end{array}$ & $\begin{array}{l}n \text { Am. } \\
\text { J. } \\
\text { Med. } \\
1980\end{array}$ \\
\hline $\begin{array}{r}\text { Kono et } \\
\text { al }\end{array}$ & 23 & M & $120 / 60$ & 1.9 & 0.16 & 641 & adenoma & $\begin{array}{l}\text { normol pressor response to } \\
\text { anglotensin II or nor- } \\
\text { epinephrlne, ? defect of } \\
\text { preexisting factor }(B \mid g l \text { ler }\end{array}$ & $\begin{array}{l}\text { J. } \\
\text { Clin } \\
\text { End. } \\
\text { I) Iret }\end{array}$ \\
\hline $\begin{array}{l}\text { Present } \\
\text { Case }\end{array}$ & 36 & $M$ & $\begin{array}{l}170 / 100 \\
\text { (OPD) } \\
110 / 70 \\
\text { IN- } \\
\text { PATIEN }\end{array}$ & 2.1 & 1.8 & 667 & adenoma & ?sodlum dependency & \\
\hline
\end{tabular}

れており(表 2 )，正常血纴の説明を循環血㓡量の 正常ないし低下に求めた場合に矛盾する点であつ た，本例の場合は，循環血浆量およびPRAは共に 正常でありこの点矛盾はない. Connのcriteriaに もあるよらに一般に原発性アルドステロン症の PRAは抑制されており ${ }^{10)}$ ，フロセマイド等による 負荷試験にも上昇がみられない11。しかし腎障害 を伴つた例あるい㥙悪性高血圧に陷つた例では PRAは上昇する，本例では腎機能は正常範囲内で あり，腎組織も腎石灰化を除いては正常であり， 腎障害によるPRAの上昇とは考皇にくい，末た本 例は未治療患者であり，スビロノラクトンなどに よる長期治療の影響も否定できる。 Weinberger ら ${ }^{11)}$ の最近の多数例の集計では，20例中 5 例は PRAのbesal值は正常範囲内之考えられるが，フ ロセマイド負荷後の値はすべて正常範囲以下とな つている，従つて本例のように原発性アルドステ ロン症でありながらPRAが正常であり，Juxtaglomerular index も正常であることは特異なこと であり，本症の正常血王，正常循環血浆量と関連 している可能性がある。表 2 に揭げた以外に Brooks $^{21}$ は副腎癌による原発性アルドステロン
症を報告しており，この例では正常血圧，正常 PRAであり，その理由として発症が急であり高ア ルドステロン㱏の期間の短さを挙げている，我々 の症例はその罹病期間は数年以上であり，この点 からは説明不能である。

正常血王を示す原発性アルドステロン在は表 2 に示したよ5に4例報告されて和り，引ち3 例は 腺腫，1例は車側過形成である。正常血圧の原因 としては，昇圧ホルモンに対する血管反応性の低 下，降王系機作の立進，DOCなど共存ホルモンの 久如, 罹病期間の短さなどがあげられているが(表 2)，本例では，これらいずれによつても説明でき ない，本例の血圧は，一部食塩依存性であり，術 後血王は一段と降下している点から, Shirotoら の説明のよ5に本来低血圧が存在している可能性 があり，さらにその原因として堅に扣けるNa培失 傾向が考えられる、しかしながら $\mathrm{Na}$ 輩失を来すよ うな病因として, Bartter症候群の合併は尿細管 $\mathrm{Cl}$ 再吸收試験 ${ }^{8}$ が正常なこと, 術後低カリウム血症 がないことなどから否定でさる。抗ミネラルコル チコイドの過剰産生は血中プロゲステロン， $17 \alpha$ OH・プロゲステロンが正常なことより否定され， 
カリクレインーキニンープロスタグランディン系 の異常元進の可能性については，尿中カリクレイ ン排泄量は従来の報告にみられる程度の上昇であ $ク^{13)}$ ，なた尿中，血中PG排泄量が正常なこと， ibuprofene投与で血压に変化がみられないことよ りこの可能性も否定できる。

本定ら ${ }^{14)}$ は，スピロノラクトン中止後も血圧上 舁のみられない原発性アルドステロン症の 1 例を 報告し，極度の減塩がその一因と推定しているが， 本症では増塩食後もやや昇厈するるのの高血圧と はならず，このよらな可能性す否定される。

正血圧性原発性フルドステロン症の病態, 特に 正血圧の原因は文献例㧊よび今回の自験例におい てはな持不明といわざるを得ないが，前述したよ うな多因子が複雑に関係して生じているものと考 号れ，さらに今後の症例の検討が期待される.

\section{結語}

腎石灰化症を伴つた正レニン性正血王性原発性 アルドステロン症の 1 例を報告するとともに, 本 症に括ける正血王の原因について内分泌的検討を

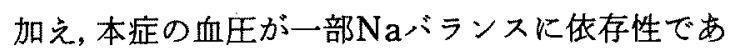
ることが判明したが，既知の $\mathrm{Na}$ 喪失因子，降圧性 ホルモンの六進は否定的であつた.

謝辞 睡湯中ステロイドホルモンの測定をしていたたい た東北大学第二病理 小島元子博士, ブロスタグランディ ンの測定をしていだいた小野薬品研究所に感謝します。

本研究の一部憬生省特定疾患「ステロイドホルモン産 生異常症」班, 文部省科学研究(特定研究) 費の援助を受 けた。

\section{文献}

1) Snow $\mathrm{MH}$, et al: Normotensive primary aldosteronism. Brit Med J 1: 1125, 1976.
2) Zipser RD and Speckart PF: "Normotensive" primary aldosteronism. Ann Intern Med 88: $655,1978$.

3) Shiroto $\mathrm{H}$, et al: Normotensive primary aldosteronism. Amer J Med 69: 603, 1980.

4) Kono $T$, et al: Normotensive primary aldosteronism: report of a case. J Clin Endocrinol Metab 52: 10091981.

5) Maruyama A, et al: Long term effects of captopril in hypertension. Clin Pharmacol Ther 28: 316.1980.

6) Ogihara $T$, et al : Sodium depletion and blood pressure response to 1-sarcocine, 8-isoleusine angiotensin II in hypertension. Clin Pharmacol Ther 23: 316, 1980.

7) Saruta $T$, et al: Relationship between serum renin concentrantion, renal renin content, and juxta-glomerular apparatus in hypertensive patient. Jpn Circul J 33: 913, 1969.

8) Gill JR Jr and Bartter FC: Evidence for a prostaglandin-indepencdnt defect in chloride reabsorption in the loop of Henle as a proximal cause of Bartter's syndrome. Amer J Med 65: 766, 1978.

9) Glaz E: Aldosterone. Pergamon Press, Oxford, 1971, p 175.

10) Conn JW, et al: Preoperative diagnosis of primary aldosteronism. Arch Intern Med 123: 113, 1967.

11) Weinberger $\mathrm{MH}$, et al: Primary aldosteronism. Ann Intern Med 90: 386, 1979.

12) Brooks RV, et al: Hyperaldosteronism from adrenal carcinoma. Brit Med J 1: 220, 1972.

13）中透，他：尿中カリクレイン。臨床科学 $16: 889$, 1980.

14）本定 晃, 他： Spironolactone治療中止後正 常血压を維持している原発性アルドステロン症の 1 例. 日内会誌 $69: 884,1980$. 